\title{
Pedal Edema
}

National Cancer Institute

\section{Source}

National Cancer Institute. Pedal Edema. NCI Thesaurus. Code C80306.

The accumulation of fluid in the feet, most prominently on the dorsum. 